\title{
EXECUTIVE COACHING EXPERIENCES. A SYSTEMS PSYCHODYNAMIC PERSPECTIVE
}

\author{
FRANS CILLIERS \\ Department of Industrial \& Organisational Psychology \\ UNISA
}

\begin{abstract}
The Integrated Executive Experiential Learning Coaching model was applied in an information technology organisation. The aim of the research was to analyse and interpret the experiences of seven executives in the form of written essays from the systems psychodynamic perspective. The manifesting themes were, experiential learning facilitates the working through of defences; interdependency facilitates taking responsibility for the self; flight reactions inhibit owning and learning; transcending defences is needed to authorise the self in role; the difficulty of moving from the paranoid-schizoid to the depressive position and valuing all parts of the self; and containment facilitates self-authorisation. Recommendations towards more effective executive coaching are presented.
\end{abstract}

\section{OPSOMMING}

Die "Integrated Executive Experiential Learning Coaching model" is toegepas in 'n inligtings tegnologie organisasie. Die doel van die navorsing was om die ervaring van sewe uitvoerende beamptes in opstel-formaat te analiseer en te interpreteer vanuit die stelsel psigodinamiese benadering. Die manifesterende temas was, ervaringeleer fasiliteer die deurwerk van verdedigingsmeganismes; interafhanklikheid fasiliteer die neem van selfverantwoordelikheid; vlug reaksies inhibeer eienaarskap en leer; die transendering van verdedigings is nodig vir self outorisering; die moeisaamheid van beweeg vanaf die paranoide-skisiode na die depressiewe posisie en waardering van alle gedeeltes van die self; en behouering fasiliteer self-outoriteit. Aanbevelings vir meer effektiewe uitvoerende afrigting is aangebied.

The post-modern work environment is associated with various new constructs such as the new economy, globalization, change, transformation, diversity management, mergers, acquisitions, increased competition and complexity (Clutterbuck, 2003). These constructs facilitate heightened levels of anxiety because of changes in the nature of psychological boundaries within and between systems (individual, teams, organisation), and the demand to take up multiple (especially leadership) roles in complex matrix systems (Huffington, Armstrong, Halton, Hoyle \& Pooley, 2004). According to Price (2003a; 2004d; 2004e), executive coaching is one of the new management tools to cope with these changes and complexities. It offers a highly focussed and fast learning opportunity to compensate for lengthy training sessions and its methods where learning content is becoming obsolete at an increasingly fast rate.

Although organisational coaching can be traced back to the 1940s (Lowman, 2002), its broader application has only gained momentum in the late 1990s. Internationally, the American Psychological Society (Division 14) layed down standards for executive coaching (Stern, 2001) which is supported by substantial - especially North American - research results (for example by Brotman, Liberi \& Wasylyshyn, 1998; Garman, Whiston \& Zlatoper, 2000; Goldsmith, Lyons \& Freas, 2000; King \& Eaton, 1999; Peltier, 2001; Peterson, 1996; Sperry, 2004; Witherspoon \& White, 1998). Almost all articles and chapters start with the definition of executive coaching as compared to mentoring, counselling and therapy, and how coaching should be 'rolled-out' in different organisations. This finding as well as the lack of clear empirical evidence of behavioural and organisational change, could be indicative of the still unclear identity boundaries of executive coaching as a fairly new organisational endeavour.

In South Africa, coaching enjoys professional recognition in the existence of the SA Council of Coaches and Mentors (SACCM) (Bjorkman \& Van Niekerk, 2003). The South African literature on executive coaching is mainly found in popular journals on general and human resources management (Clutterbuck, 2003; Meyer \& Fourie, 2004a; 2004b; Price, 2003a; 2003b). These articles focus on the practical 'how to do'

Requests for copies should be addressed to: F Cilliers, cillifvn@unisa.ac.za executive coaching and claims that its practice will result in increased management and leadership competence, strategic thinking, intellectual capacity, wisdom, empowerment, relationship management as well as the solving of business problems (Johnson \& Cohen, 2004; Knouldts, 2004; Price, 2003c; 2004b; 2004c; Van Wyk, 2003; Will \& Codrington, 2004; Willem, 2002; 2003). Unfortunately, no South African academic and scientific research with reference to the psychological effects of executive coaching could thus far be found as evidence of the above claims.

\section{Executive coaching described}

Many definitions of executive coaching exist (see Brotman, Liberi \& Wasylyshyn, 1998; Clutterbuck, 2003; Garman, Whiston \& Zlatoper, 2000; Goldsmith, Lyons \& Freas, 2000; Kilburg, 2000; King \& Eaton, 1999; Meyer \& Fourie, 2004b; Peltier, 2001; Peterson, 1996; Sperry, 2004; Witherspoon \& White, 1998). All these definitions refer to the core of executive coaching as a specific form of organisational and staff development and a specific kind of interpersonal relationship. Some refer to the stimulation of and personal process of growth in the executive, while others refer to outcomes such as enhanced performance in leadership and transformation roles.

For purposes of this research executive coaching is defined as a form of consultation, namely a formal, ongoing relationship between (1) an individual or team having executive (including managerial and leadership) authority and responsibility in an organisation, and (2) a consultant who possesses in-depth knowledge of behaviour change and organisational functioning from various psychological perspectives and paradigms (Hall \& Duval, 2004; Hillary, 2003; Huffington, Armstrong, Halton, Hoyle \& Pooley, 2004; Lowman, 2002; Peltier, 2001; Schein, 2005; Sperry, 2004; Tönsing, 2003). The underlying facilitative process involves the provision of learning opportunities towards selfawareness, self-esteem and increased quality in the communication with colleagues, peers and subordinates, especially with regards to the individual's leadership role and accompanying authorisation. The techniques include giving direct behaviourally based feedback and interpretations about the executive's impact on others, both within and 
outside of the organisation, thus creating opportunities for change and demanding accountability for the outcome. It is believed that the measurable behavioural change in the individual or team will result in increased performance on the individual, team and organisational levels.

\section{The efficacy of executive coaching}

On the macro level studies on the efficacy of executive coaching (Lowman, 2002) claim the enhancement of organisational morale, productivity and profits. Unfortunately these studies mostly hypothesise about the outcomes without it being substantiated by empirical designs and methods. On the micro and individual level the research suggests that (1) the executive finds the experience beneficial and believes that he/she receives a high return on investment, and (2) that various types of executive coaching approaches do impact positively on self-awareness, self-development, improved relationships with superiors, subordinates and clients, leadership effectiveness, teamwork, conflict reduction, commitment, satisfaction, performance and productivity (Peltier, 2001). Yet, these results do not refer to the individual's learning about his/her own behavioural dynamics and its effect on the rest of the system.

According to Kampa and White (in Lowman, 2002), executive coaching efficacy depends on three variables, namely the growth in the executive, the coach's skills and the quality of the interpersonal relationship. Further investigation of this literature showed the following:

- The growth of the executive is described in most of the literature in terms of his/her self-efficacy, referring to Bandura's (1997; Wood \& Bandura, 1989) concept and defined from the behaviouristic perspective as having the belief that one has the capabilities to mobilise the motivational and cognitive resources, and courses of action needed to meet given situation-demands. Price (2004a; 2004b) for example, described the growth in terms of wellness and strengths, but without giving a scientific and psychological conceptualisation of the nature of these terms.

- The coach's skills are described in most of the literature as a special kind of communication style, including active listening as the necessary core quality to facilitate learning in and for the executive (Lowman, 2002). Peltier (2001) refers to executive coaching as a mainstream leadership skill including management functions (such as planning, decision making, chairing a meeting, writing skills, delegation, dealing with difficulty, project and conflict management, team building and coping with diversity), interpersonal communication (listening, assertiveness, giving feedback), and the understanding of and working with organisation culture.

- The quality of the relationship between the two roles is described as the most critical component of executive coaching. Almost all the literature conceptualises the relationship referring to aspects of the person-centered facilitation perspective (Cilliers, 1995; 1996; 2000). This includes listening supported by the core dimensions of realness, openness, honesty, respect and empathy, which, according to Rogers (1982), will facilitate a meaningful experiential encounter of the other. Unfortunately, the executive coaching literature does not operationalise the relationship to the depth as researched by Rogers and operationalised in existing helping models (eg. Carkhuff, Ivey, Egan - see Cilliers, 2000). Actually, Rogers (1982, in Schneider, Bugental \& Pierson, 2001) cautioned that his work should not be trivialised in organisational applications. In this context, Kramer (1995) illustrated how active listening is easily forced into a tool to enhance productivity (rather than a skill to build relationships) and Cilliers $(1991 ; 1992 ; 1995)$ illustrated how the concepts of facilitation and empathy are used superficially in training, management and organisational development. Using these facilitative conditions in executive coaching, will require a high level of training to provide a trusting and respectful environment for the executive to experience the freedom to learn as well as the coach's continuous development towards self-actualisation.

\section{Paradigms in studying executive coaching}

An analysis of the above literature indicated that executive coaching is generally studied from the behaviouristic (eg. selfefficacy) and humanistic paradigms in psychology (eg. clientcentered facilitation). Price's (2004a; 2004b) references to wellness and strengths could refer to what is being studied in the positive psychology paradigm (Sheldon \& King, 2001; Snyder \& Lopez, 2002). Unfortunately these descriptions are vague in terms of psychological functioning (compared to how well it is explicated in Lindley \& Joseph, 2004). On the one hand, the study of executive coaching from the above paradigms ensure that the interpersonal relationship and its outcomes are understood from a cognitive and immediate relationship perspective. On the other hand, it avoids understanding the dynamic and unconscious nature of the coaching relationship as well as the individual's dynamic team and organisational relationships and relatednesses (as was the aim in this research).

\section{The Integrated Executive Experiential Learning Coaching model (IEELC)}

This model, designed by Chapman (2004) was used in this research. It conceptualises executive coaching as a form a consulting, combining the Wilber Integrative (interior/exterior and individual/collective) and Kolb Experiential Learning models (monologue/dialogue I/we/it), while integrating the hierarchical evolution of consciousness. It operationalised coaching as the facilitation of self-organised learning in adults through experiential learning conversations in order to grow and improve performance. The technique of self-organised learning is the conversational construction, reconstruction and exchange of personally significant, relevant and viable meaning with awareness and controlled purposiveness. This is applied to the one-on-one coaching situation and includes strategy formulation, implementation via the balance scorecard from an architectural approach, organisational complexity and Jaques' Leadership Competency model - including cognitive processes and power, knowledge and skills, personality, temperament and style. It distinguishes between the styles of the master, the dabbler, the obsessive and the hacker.

From a research point of view, the IEELC model offers opportunities to study specific organisational constructs such as management, leadership, personal growth, commitment and involvement on the conscious level. At the same time it offers the opportunity to study the dynamic nature of the executive's relationships and relatedness on the unconscious level from a systemic point of view (from the intrapersonal to the collective) by means of experiential learning. This includes the struggle to take up and authorise the self in role as a leader, to offer containment in this role to the self, others and the organisation, to move from dependence to interdependence, and to investigate defensive reactions, which all make this model appropriate for inclusion in this research.

\section{The systems psychodynamic perspective}

The conceptual origins of the systems psychodynamic perspective stems from classic psychoanalysis (Freud, 1921), group relations theory and open systems theory (De Board, 1978; French \& Vince, 1999; Hirschhorn, 1993; Miller, 1993; Obholzer \& Roberts, 1994). This perspective is based upon the following five basic assumptions acting as the cornerstones for studying relationships in organisational systems (López-Corvo, 2003; Miller, 1993; Rice, 1965): Dependency (the group's unconscious projection for 
attention and help onto an authority figure as parental object); fight/flight (a defence mechanisms in trying to cope with discomfort, involving the authority figure for example management or leadership); pairing (unconsciously connecting with perceived powerful others such as the manager or leader, or splitting the authority figure(s) as an individual or as a pair in order to be able to identify with one part as a saviour - Bion, 1961; 1970; Lipgar \& Pines, 2003); one-ness (also referred to as me-ness by Turquet, 1974) (the individual's escape into his/her own fantasy and inner safe, comfortable and good world, whilst denying the presence of the group, seen as the disturbing and bad part); and we-ness (the opposite of me-ness, and the unconscious need to join into a powerful union with and absorption into an omnipotent force, surrendering the self in passive participation - Lawrence, Bain \& Gould, 1996).

\section{The systems psychodynamic consulting stance}

The systems psychodynamic perspective is a developmentally focussed, psycho-educational process for the understanding of the deep and covert behaviour in the system. Its primary task is formulated as pushing the boundaries of awareness to better understand the deeper and covert meaning of organisational behaviour, including the challenges of management and leadership (Koortzen \& Cilliers, 2002; Miller \& Rice, 1976).

The systems psychodynamic consultant engages in an analysis of the interrelationships of some or all of the following: boundaries, roles and role configurations, structure, organisational design, work culture and group process (Miller, 1993; Neumann, Kellner \& Dawson-Shepherd, 1997). The consultant is alert to, hypothesises about and interprets the covert and dynamic aspects of the organisation and the work group that comprise it, with the focus on relatedness, representation and how authority is psychologically distributed, exercised and enacted, in contrast to how it is formally invested (see Haslebo \& Nielsen, 2000). This work includes a consideration of attitudes, beliefs, fantasies, conflicts, core anxieties, social defences, patterns of relationships and collaboration, and how these in turn may influence task performance; how unwanted feelings and experiences are split off and projected onto particular parts (individuals or groups who may have the valance for receiving and carrying the specific projections), that contain them on behalf of the system (their projective identifications and process roles as distinct from their formally sanctioned roles); and how work roles are taken up, especially leadership and followership. Menzies (1993) emphasised the analysis of social defence aspects of structure and its relationship to task and process, thus trying to understand how unconscious anxieties are reflected in organisational structures and design (which function as a defence mechanism). The stance studies the system as a reality as well as 'a system in the mind' in its totality (groupas-whole), and its dynamic movement from basic assumption group functioning and the paranoid-schizoid position towards interdependence, characterised by work group functioning and the depressive position (Colman \& Bexton, 1975; Colman \& Geller, 1985; Cytrynbaum \& Lee, 1993; Czander, 1993; Gabelnick \& Carr, 1989; Gould, Stapley \& Stein, 2001; Neumann, Kellner \& Dawson-Shepherd, 1997; Shapiro \& Carr, 1991; Stapley, 1996; Wells, 1980).

Thus, the stance studies the emotional task of the organisation which is filled with chaos, a lack of control and difficult experiences such as competition, rivalry, jealousy, envy, hate, hostility and aggression (Miller, 1976; 1993). As a result, leadership (as the focus in executive coaching) becomes difficult (if not impossible) and the relationships and relatedness between subsystems as well as the containment of these, become increasingly complex. As a result, mistrust and distrust increase (indicating the prevalence of paranoid fear, and a lack of meaning and hope in the system). Because leaders seem to find themselves de-authorised to negotiate new roles within their organisations directly, the system creates new mechanisms as a defensive compensation for the loss of control (Huffington, Armstrong, Halton, Hoyle \& Pooley, 2004). The systems psychodynamic approach believes coaching to be one of the modern defences against the increasing organisational complexity, role ambiguity, high levels of anxiety and loneliness.

This research endeavoured to integrate the above systems dynamic behaviours as an interpretive stance towards exploring executive coaching experiences operationalised in the IEELC model. As an argument towards relevance and compatibility between the stance and the model, the following is offered: Both the interpretive stance and the operational model are based upon well grounded, structured and contained scientific backgrounds, both focus on conscious and unconscious behaviour from a system perspective, and on how the individual takes up the role towards higher levels of functioning. One major difference is the focu within the systems psychodynamic stance on object relations based on Klein's $(1959 ; 1975)$ theory of how objects could have representative value for one another (which were included in this research).

\section{Problem statement and aim}

The conceptual and operational identity of executive coaching as a fairly new organisational endeavour, is still unclear. Conceptually it struggles to find its place somewhere between training, development, mentoring, counselling and therapy. Operationally, its research is based upon popular and untested assumptions about its effect and influence on the executive, especially in the long term, as well as on the organisation. In practice, various helping models are used in executive coaching, but there is limited evidence of the effect of different paradigms on outcomes.

The aim of this research was to offer a systems psychodynamic interpretation of executive coaching experiences amongst a group of IT specialists/executives to offer this stance's view on behavioural change during executive coaching.

\section{RESEARCH DESIGN}

\section{Research approach}

The approach was qualitative and explorative in nature. More specifically, the social phenomenologiocal approach was used (Higgs \& Smith, 2003). This entails that the researcher will not be intimidated by social power or status, and be concerned with the relevant values and ethics. The researcher asks the question, 'what is actually happening', while exploring, 'looking again' and then reflecting in ruthless honesty. Thus, the researcher attempts "to penetrate the illusion in order to get to the reality underlying the illusion" (Higgs \& Smith, 2003, 67).

\section{Research methodology \\ Participants}

The research was done in an international information technology organisation. An executive coaching programme was introduced in 2001 for a two year period consisting of individual, bi-monthly, two hour sessions, using the Integrated Experiential Learning Coaching Model. A sample of seven executives being coached by the same coach was used.

\section{Data collection technique}

Data was collected by means of essays written by participants. The essays were seen as transcriptions representing the experience of each participant (Camic, Rhodes \& Yardley, 2003, 82-83). 


\section{Data collection procedure}

Each participant was asked to: "Write an essay of about 5 pages on your experiences of the coaching and the coaching relationship'. The essays were received electronically and then printed out.

\section{Data analysis}

To best accomodate the explorative nature of the approach, content analyses was used (Camic, Rhodes \& Yardley, 2003), consisting of breaking down, examining, comparing, conceptualising and categorising of data. Firstly, the responses were read through a couple of times for familiarisation of content. Thereafter, true to the systems psychodynamic interpretive stance, Schafer's (2003) guidelines were used towards the formulation of working hypotheses (also see Haslebo \& Nielsen, 2000) on the manifestation of the basic assumptions and its associated anxieties and conflicts (see Menzies, 1993; Neumann, Kellner \& Dawson-Shepherd, 1997). Different examples were clustered (see Brewerton \& Millward, 2004; Clarkson \& Nuttall, 2000) leading to the prominent themes. Trustworthiness was ensured (as defined by De Vos, 2002) by having the findings examined by a psychologist, to whom this research method and interpretive stance were well known.

\section{FINDINGS}

The following six themes manifested.

\section{Experiential learning facilitates the working through} of defences

Participants expressed their need to be instructed and taught by the coach, and not to be 'facilitated in this open and vague' manner. It seemed that the nature and method of experiential discovery as a way of learning and thus explicating inner experiences in order to develop shared models of reality (Bion, 2003; Gould, Stapley \& Stein, 2001), created a high level of anxiety amongst this group if IT executives. Using Stapley's (1996) description of organisational culture as the personality of the organisation, it was interpreted that this anxiety reflects the existing organisational culture where anxiety is contained in structure and procedure. This scenario has lead to rigidity and a mechanistic way of operating, rather than to dynamically investigate evidence in the here-and-now as learning opportunities. There is also a lack of trusting in one's own experience or to freely explore and discover the nature of dynamic relationships in the system.

The participant's anxiety manifested in various ego defences, namely intellectualisation (trying to keep their learning on the cognitive level and not make contact with difficult and disturbing feelings), rationalisation (giving intellectual explanations for their behaviour), denial (not wanting to work with the difficulty of introspection and 'soul searching'), regression (referring to childhood experiences suggesting that the coach represented a parental figure - not realising their own transferences) and projection (of incompetence onto the coach for 'not helping' them). These defences represented the participant's immaturity at the beginning of the executive coaching relationship (see Gabelnick \& Carr, 1989).

As the work continued, the experiential nature of the executive coaching model made an appeal on the participant's ego strength to stay with and work through their anxieties and difficulties. Towards the end of the coaching contract the neurotic agendas of moaning (about management) and blaming (the organisation) used by most participants, diminished and were replaced by selfauthorisation and working towards openness and a shared reality in the coaching relationship. Generalising from Menzies' (1993) theory, this could be interpreted as happening because the individuals experienced containment in the executive coaching relationship, the climate and its culture. According to Horney's theory (1950; 1957) the participant's behaviour moved from (only) working against the coach and what he represented, towards integrating the three neurotic tendencies of moving towards, away from and against their objects, in exploring their relationship and work behaviour.

\section{Interdependency facilitates taking responsibility for} the self

Many participants expressed dependence on the coach as a parental and authority figure, an experienced expert, director and guide of their development. This means that they expect him to 'help them to become more successful as employees and leaders in this organisation'. Unconsciously, he represented the object of wisdom and the accompanying fantasy was that he will take charge of their learning and instruct them 'what to do'.This transferential relationship tries to pull the coach into a rescue mentality (Huffington, Armstrong, Halton, Hoyle \& Pooley, 2004) while the participants split off their own competence, and project this onto the experienced expert. This behaviour also represents their attempt to seduce the coach out of his authorised role into carrying and containing the participant's immaturity and incompetence (Shap[iro \& Carr, 1991).

In spite of the above transferences and projections, the coach stayed in his authorised role. This may be an indication of the level of organisational authorisation given to him from above (see Obholzer \& Roberts, 1994), specifically from the human resources director who acted as custodian for executive coaching and who contracted this role with him.

The participants reacted with intense feelings of frustration anger and hostility as a manifestation of their counter dependance (see Bion, 2003) and rebellious child ego state (Berne, 1961). This behaviour was an attempt to take up their roles in the coaching relationship, but with pseudo authority, because it was still filled with transferences and projections as if they were playing the game of 'getting-my-own-way' (Bennett, 1976).

Most participants did not stay in this counter dependent position for long. This was interpreted as therapeutic movement (see Czander, 1993), based on the knowledge that the group was especially selected on the grounds of their intelligence and high potential for development. Hereafter all participants moved to the independent position, where some stayed for some time and two participants never moved out of. This was interpreted as a manifestation of me-ness - it was as if the participants found a new independent position where he/she can show of strength and power and stay separate and unattached from others (see Turquet, 1974). This behaviour could also be seen as a defence (for example compensation) for the lack of an experienced independence in their functional roles and in the organisational culture. The core of this defence could be the need to hang on to power and to serve the narcissism which normally forms part of a power play (Peltier, 2001).

Most of the participants moved to the interdependence position where they could work productively, experiencing their own needs, thoughts, feelings and drives without defending as strongly as in the beginning. This position does not imply that the individual 'has arrived', but the position supplied him/her with the resilience to explore and address deeper experiences and integrate these into his/her ego functioning (Gould, Stapley \& Stein, 2001). The underlying process implies that the participants increasingly took responsibility for themselves in owning their behaviour as it enters consciousness (Cytrynbaum \& Lee, 1993). 
3 Flight reactions inhibit owning and learning

The initial discomfort in coping with the limited structure in the experiential executive coaching design, lead to flight reactions as a defence mechanism. Initially, participants referred to many past and 'out there' events and situations, which lessened as the coaching sessions progressed. This was interpreted as the participants getting used to taking up their authority in their roles as learners (Clarkson \& Nuttall, 2000) and in exploring the content and intensity of the here-and-now situation. This implied a letting go of defences and game playing. When this happened, the learning became more personalised and owed as if the participant had to go though some kind of psychological birth process in trusting the coach as an outsider looking inside towards their environments, situations and personal experiences. The resulting trusting relationship showed clear evidence of self-empowerment amongst the participants. Sievers (2002) referred to the dynamics of trust being embedded in the level of meaning the participant experiences in the relationship and the accompanying hope to sustain the interaction and the learning. This was evident in their references to finding deep meaning in the here-andnow of the learning event as well as the application of the learning in their work teams.

\section{Transcending defences is needed to authorise the self} in role

Initially, splits manifested between what the participants apparently experienced and felt, versus what they verbally communicated, which resulted in the many defences being used. Because of the inner turmoil, it was difficult to trust and therefor be honest and open in their experience of themselves. It took some time for most participants to realise that their experience of 'I do not trust the coach' was a projection of their distrust towards themselves for confronting the self with seemingly threatening information. In general this behaviour is linked with authorisation to take up a leadership role (French \& Vince, 1999). Three participants referred to the realisation that 'putting the parts of the self together' is important for learning, growth, selfintegration and taking up the leadership role. This is what Peltier (2001) referred to as self-management and Miller (1993) as wisdom, which is needed for the participant to authorise the self in role, especially of leader in complex matrix systems.

5 It is difficult of moving from the paranoid-schizoid to the depressive position and valuing all parts of the self During the initial and immature stage of the relationship between the participant and coach, many schizoid splits occurred. This is seen as typical in many types of immature organisational relationships (Hirschhorn, 1993). For example, participants tried to split off and project the parts of themselves they perceived as bad. These were their fears of being part of this competitive organisation, colleagues they do not get along with, people in the organisation seen as dangerous or strict, and their incompetence and noncoping with specific organisational demands. In many occasions the participants unconsciously used the coach to carry these anxieties on their behalf. Thus external figures and structures were created who are both hated and feared, in order for the insider (the participant) to feel safe and secure (Colman \& Bexton, 1975; Colman \& Geller, 1985). The projection of badness to the outside of the self was used to simplify psychic complexities in the self and the organisation and to produce a state of illusionary goodness and self-idealisation. This lead to the experience of fragmentation in the participant, because contact was lost between parts of the self - which needed to connect in order to act as a whole person (see Menzies, 1993).

The above anxiety were prosecutory in nature (see Lipgar \& Pines, 2003) and resulted in paranoia-genesis (see Gould, Stapley \& Stein, 2001) where the individual is experiencing the bad parts of the self as situated within the other, who becomes 'the enemy' and the receiver of unwanted projections. It took some time for participants to work through and finding out who his/ her 'enemy' was and how he/she related towards the enemy, before a satisfactory level of insight and understanding could be reached. De Jager, Cilliers and Veldsman (2004) referred to the unconscious collusions happening in cases such as the above, especially in organisations where anxiety is contained in having many structures, rules and procedures. This defence structure occurred amongst most of these participants. It was interpreted that participants got stuck within their safe boundaries, and did not manage to integrate both parts of the split into their own ego boundary.

On the other hand, there were two participants who showed some resilience towards movement to the depressive position (see Colman \& Bexton, 1975; Colman \& Geller, 1985), indicating their maturity to recognise that their painful feelings come from their own projections, and not an outside source. This was followed by being brave enough to own their projected material and to return their received projections to its source, saying for example, 'these are my feelings, not yours/ those are your feelings and not mine'. The two mentioned participants stayed within this position where projections are ricocheting back and forth for quite a while, during which the coach respectfully reflected and interpreted the behaviour, until there was enough evidence to let go of the feelings and to reflect on them. The maturity aspect in this action lies in the re-owning of parts of the self which lead to decreased splitting, polarisation and antagonism. Why only two participants reported on having this sense of integration within their own egos, could relate to many aspects, such as the individual's valence for development towards maturity (French \& Vince, $1999)$ or the experiential nature of the coaching relationship (Peltier, 2001; Stapley, 1996).

\section{Containment facilitates self-authorisation}

Many participants ended their essays referring to the nature and quality of the relationship between themselves and the coach. This could refer to their experience of containment, defined as a state of integration in terms of a reciprocity between two parts - a containing function and a contained function, in this case a coach and a participant (Huffington, Armstrong, Halton, Hoyle \& Pooley, 2004). When this function breaks down, the individual could experience catastrophic anxiety, and when it is held up, the individual can integrate. These participants experienced the holding quality of the containment which lead to their taking up of their authority to learn and integrate the learning into their organisational roles, especially their leadership roles. This meant that participants could manage the boundaries between the inside and the outside - which is how leadership is defined in this stance (Obholzer \& Roberts, 1994). It was interpreted that the participants experienced being authorised from above (firstly by the organisational system in selecting them to be part of the executive coaching programme and secondly by the coach during the sessions), and from within (by allowing the self to integrate the learning about the self and their relationships). This self-authorisation facilitated their increased understanding of their role(s) as well as its demands on the self (inside the own boundary) and others (across the boundary). They reported being recognised by their superiors as someone who has a valuable place in the larger organisational system, that they had more effective interpersonal and supervisory communication with colleagues and followers, and more awareness of their own team's dynamic behaviour. 


\section{DISCUSSION}

The findings showed that this specific executive coaching relationship has empowered and authorised the executives in taking up their organisational leadership roles. They started the sessions with being dependent on a 'guru' whilst projecting their own insecurities and incompetence on him, with the unconscious expectation that he will teach them and help them carry the psychological burden of learning. Through the exploratory and experiential learning process, they realised that this position of dependence with all its accompanying immature splits, was withholding them from moving towards maturity and interdependent functioning. The individual process of growth seems to be filled with lots of effort and difficult learning - yet the outcome seemed to be successful in providing opportunities to work through personal defences, towards the owning of some unconscious behaviour (see Obholzer \& Roberts, 1994).

Most participants could work through their basic assumption behaviour (of dependence and flight) but not all participants could move beyond the paranoid-schizoid position. This is not surprising, seeing that a system never completely transcends this position (French \& Vince, 1999; Miller \& Rice, 1976) and the depressive position is never attained for long (Colman \& Bexton, 1975; Colman \& Geller, 1985).

The findings showed how executive coaching resembles the family dynamic of children acting towards parental figures and using them as objects for projections and projective identification (Miller \& Rice, 1976). This emphasised the importance for executive coaches to contain anxiety on behalf of participants, especially during the initial phase of the contract and the relationship. It seems that this model as applied to these executives offered them the opportunity to explore the meaning attached to their various organisational roles in the here-and-now as well as what is hoped for in future - in short how trust manifests in his/ her work relationships.

\section{CONCLUSION}

It was concluded that this executive coaching model of integrated systems learning, facilitated psychodynamic insight and wisdom in individual participants. They understood and owned important behavioural dynamics inside of themselves, between themselves and other significant colleagues. This underlines the possibilities of executive coaching as a staff development intervention to facilitate self authorisation by working through own splits and projections. It was hypothesised that executive coaching presented from this model empowered individual employees to work towards their own cognitive insight, the experience of emotional meaningfulness and the taking of responsibility for their own growth and career development.

These findings link with all three types or functions of executive coaching mentioned by Sperry (2004), namely, skill-focussed, performance-focussed and development-focussed coaching. Participants reported enhanced functioning in terms of skills (relating to the process and method for learning used, operational leadership, analytical ability, awareness of dynamic behaviour in human relations and relatedness, strategy and selfmanagement), in terms of performance (functioning significantly more empowered and authorised as leaders and executives), and in terms of development (having clear steps implemented towards personal and professional transformation and career development).

It seemed that executive coaching is a powerful organisational learning opportunity (see Price, 2003a), which could be approached from different psychological perspectives and paradigms. But, this means that the different views need to be scientifically investigated before general claims of its effectiveness can be made. This research indicated that the systems psychodynamic consultancy stance facilitated awareness around its basic assumptions and empowered the executive to effectively take up the role of leader.

Because executive coaching is a fairly new organisational endeavour, its long term effect on the individual's growth and career is not yet clear, as is the effects on the larger organisational system, for example morale, productivity and profits. It is suggested that continued research is done within the systems psychodynamic consultancy stance to ascertain this effect on organisational climate, culture and trust relationships

\section{REFERENCES}

Bandura, A. (1997). Self-efficacy: the exercise of control. New York: Freeman.

Berne, E. (1961). Transactional analysis in psychotherapy. New York: Ballentine.

Bennett, D. (1976). TA and the manager. New York: Amacom.

Bion, W.R. (1961). Experiences in groups. London: Tavistock Publications.

Bion, W.R. (1970). Attention and interpretation. London: Tavistock Publications.

Bion, W.R. (2003). Learning from experience. London: Karnac

Bjorkman, D. \& Van Niekerk, P. (2003). Coaching and mentoring gains professional status. Management Today, 19 (5), 41-42.

Brewerton, P. \& Millward, L. (2004). Organisational research methods. A guide for students and researchers. London: Sage.

Brotman, L.E., Liberi, W.P. \& Wasylyshn, K.M. (1998). Executive coaching. The needs for standards of competence. Consulting Psychology Journal: Practice and Research, 50 (1), 40-46.

Camic, P.M., Rhodes, J.E. \& Yardley, L. (2003). Qualitative research in Psychology. Washington: APA.

Chapman, L. (2004). An exploration of executive coaching as an experiential learning process. Paper presented at $7^{\text {th }}$ Industrial Psychology Conference, SIOPSA, Pretoria, 25 June.

Cilliers, F. (1991). Facilitating: Making a process available. Human Resource Management, 7 (2), February.

Cilliers, F. (1992). The (ir)relevance of empathy as concept in management. Human Resource Management, 8 (3), April.

Cilliers, F. (1995). Facilitator training. Journal for Industrial Psychology, 21 (3), 7-11.

Cilliers, F. (1996). Facilitator training in South Africa. In R. Hutterer, G. Pawlowsky, P.F. Schmid \& R. Stipsits. (Eds.) Client Centred and Experiential Psychotherapy. Frankfurt am Main: Peter Lang.

Cilliers, F. (2000). Facilitation skills for trainers. Journal of Industrial Psychology, 26 (3), 21-26.

Clarkson, P. \& Nuttall, J. (2000). Working with countertransference. Psychodynamic Counselling, 6 359-379.

Clutterbuck, D. (2003). Coaching and mentoring at the top. Management Today, 19 (5),38-40.

Colman, A.D. \& Bexton, W.H. (1975). Group Relations Reader 1. Jupiter: The A.K. Rice Institute.

Colman, A.D. \& Geller, M.H. (1985). Group Relations Reader 2. Jupiter: The A.K. Rice Institute.

Cytrynbaum, S. \& Lee, S.A. (1993). Transformations in global and organizational systems. Jupiter: A.K. Rice Institute.

Czander, W.M. (1993). The psychodynamics of work and organizations. New York: Guilford Press. 
De Board, R. (1978). The psychoanalysis of organisations. London: Routledge.

De Jager, W., Cilliers, F. \& Veldsman, T. (2004). Leadership development from a systems psycho-dynamic consultancy stance. SA Journal of Human Resource Management, 1 (3), 85-92.

De Vos, A.S. (2002). Research at grass roots. Pretoria: Van Schaik.

French, R. \& Vince, R. (1999). Group relations, management, and organization. New York: Oxford University Press

Freud, F. (1921). Group psychology and the analysis of the ego. Complete works of Sigmund Freud. London: Hogarth.

Gabelnick, F. \& Carr, A.W. (1989). Contributions to social and political science. Jupiter: A.K. Rice Institute.

Garman, A.N., Whiston, D.L. \& Zlatoper, K.W. (2000). Media perceptions of executive coaching and formal preparation of coaches. Consulting Psychology Journal. Practice and Research, 52 (3), 201-205.

Goldsmith, M., Lyons, L. \& Freas, A. (2000). Coaching for leadership: How the world's greatest coaches help leaders learn. San Francisco: Jossey-Bass.

Gould, L.J., Stapley, L.F. \& Stein, M. (2001). The systems psychodynamics of organisations. London: Karnac.

Hall L.M. \& Duval, M. (2004). Neurosemantic coaching. HR Future, 4-7, January.

Higgs, P. \& Smith, J. (2003). Rethinking truth. Landsdown: Juta.

Hillary, D. (2003). Executive coaching. HR Future, 10-11, October.

Hirschhorn, L. (1993). The Workplace Within: psychodynamics of organizational life. Cambridge: MIT Press.

Horney, K. (1950). Neurosis and human growth. The struggle toward self-realisation. New York: Norton:

Horney, K. (1957). Our inner conflicts. London: Routledge \& Kegan Paul.

Huffington, C., Armstrong, A., Halton, W., Hoyle, L. \& Pooley, J. (2004). Working below the surface. The emotional life of contemporary organisations. London: Karnac.

Johnson, A. \& Cohen, D. (2004). Coaching: Adding value to a business relationship. Management Today, 20 (5), 45-46.

Kilburg, R.R. (2000). Executive coaching: Developing managerial wisdom in a world of chaos. Washington: APA.

King, P. \& Eaton, J. (1999). Coaching for results. Industrial and Commercial Training, 31 (4), 145-148.

Klein, M. (1959). Our adult world and its roots in infancy. Human Relations, 12, 291-303.

Klein, M. (1975). Envy and Gratitude and Other Essays 19461963. London: Hogarth Press.

Knouldts, F. (2004). Coaching: The internal realities of leaders. Management Today, 20 (6), 49-51.

Koortzen, P. \& Cilliers, F. (2002). The psychoanalytical approach to team development. In R.L. Lowman (Ed). Handbook of organizational consulting psychology. San Francisco: JosseyBass.

Kramer, R. (1995). Carl Rogers meets Otto Rank: The discovery of relationship. In T. Pauchant \& Associates (Eds.), In search of meaning. San Francisco: Jossey-Bass.

Lawrence, W.G, Bain, A. \& Gould, L. (1996). The fifth basic assumption. London: Occasional paper.

Linley, P.A. \& Joseph, S. (2004). Positive psychology in practice. Hoboken: Wiley.

Lipgar, R.M. \& Pines, M. (2003). Building on Bion: Branches. London: Jessica Kingsley.

López-Corvo, R.E. (2003). The dictionary of the work of WR Bion. London: Karnac.

Lowman, R.L. (2002). The handbook of organizational consulting Psychology. San Francisco: Jossey-Bass.

Menzies, I.E.P. (1993). The functioning of social systems as a defence against anxiety. London: The Tavistock Institute of Human Relations.

Meyer, M. \& Fourie, L. (2004a). Coaching and mentoring: Business tool of the 21 $1^{\text {st }}$ century. Management Today, 20 (9), 48-52.
Meyer, M. \& Fourie, L. (2004b). Mentoring and coaching. Tool and techniques for implementation. Randburg: Knowres.

Miller, E.J. (1976). Task and Organisation. New York: Wiley.

Miller, E.J. (1993). From dependency to autonomy: Studies in organization and change. London: Free Association Books.

Miller, E.J. \& Rice, A.K. (1976). Systems of organisation. London: Tavistock Publications.

Neumann, J.E., Kellner, K. \& Dawson-Shepherd, A. (1997) Developing organisational consultancy. London: Routledge.

Obholzer, A. \& Roberts, V.Z. (1994). The unconscious at work. London: Routledge.

Peltier, B. (2001). The psychology of executive coaching. Theory and application. New York: Brunner-Routledge.

Peterson, D.B. (1996). Executive coaching at work. The art of one-one-one change. Consulting Psychology Journal: Practice and Research, 48 (2), 78-86.

Price, B. (2003a). Coaching and mentoring: A perspective. Management Today, 19 (5), 44-47.

Price, B. (2003b). Coaching: Critical for the new demands of business. Management Today, 19 (4), 34-36.

Price, B. (2003c). Coaching options. Solving a wide variety of business problems. Management today, 19 (9), 48-50.

Price, B. (2004a). Coaching and mentoring. Its about concentrating on the strengths. Management Today, 20 (8), $42-45$.

Price, B. (2004b). Coaching and mentoring: Part of the company psyche. Management Today, 19 (10), 63-65)

Price, B. (2004c). Coaching sustainability, wellness and performance. Management Today, 20 (4), 46-49.

Price, B. (2004d). Coaching wisdom and magic. Management Today, 20 (3), 51-52.

Price, B. (2004e). Director of operations: A coaching experience. Management Today, 20 (2), 54-56.

Rice, A.K. (1965). Learning for leadership. London: Tavistock Publications.

Richard, J.T. (1999). Multimodal therapy. A useful model for the executive coach. Consulting Psychology Journal: Practice and Research, 51 (1), 24-30

Rogers, C.R. (1982). Freedom to learn for the 80's. Columbus: Merrill.

Schafer, R. (2003). Insight and interpretation. The essential tools of psychoanalysis. London: Karnac.

Schein, E. (2005). Course in career and executive coaching. Pretoria: Unisa.

Schneider, K.J., Bugental, J.F.T. \& Pierson, J.F. (2001). The handbook of humanistic psychology. leading edges in theory, research and practice. Thousand Oaks: Sage.

Shapiro, E.R. \& Carr, A.W. (1991). Lost in familiar places: Creating new connections between the individual and society. London: Yale University Press.

Sheldon, K.M. \& King, L. (2001). Why positive psychology is necessary. American Psychologist 56 (3), 216-217.

Sievers, B. (2002). Against all reason: Trusting in trust. Paper International Society for the Psychoanalytic Study of Organisations, Melbourne.

Snyder, C.R. \& Lopez, S.J. (2002). Handbook of positive psychology. Oxford, UK: Oxford University Press.

Sperry, L. (2004). Executive coaching. The essential guide for mental health professionals. New York: Brunner-Routledge.

Stapley, L.F. (1996). The personality of the organisation. London: Free Association Books.

Stern, L. (2001). Executive coaching handbook: Principles and guidelines for a successful coaching partnership. Boston: Executive Coaching Forum.

Tönsing, T. (2003). Coaching skills training. HR Future,26-29, April

Turquet, P.M. (1974). Leadership - the individual in the group. In G.S. Gibbard, J.J. Hartman \& R.D. Mann (Eds.), Analysis of groups. San Francisco: Jossey-Bass.

Van Wyk, L. (2003). Coaching has to deliver measurable results. Management Today, 19 (7), 49-50. 
Wells, L. (1980). The group-as-a-whole: A systemic socioanalytical perspective on interpersonal and group relations. In C.P. Alderfer \& C.L. Cooper (Eds). Advances in experiential social processes, 2, 165-198.

Will, B. \& Codrington, G. (2004). Coaching: Perspectives on leadership. Management Today, 20 (7), 51-53.

Willem, A. (2002). Coaching: Extracting intellectual capital. Management Today, 18 (9), 34-35.
Willem, A. (2003). Coaching: Obtaining wisdom from the relationship. Management Today, 18 (10), 50-51.

Witherspoon, R. \& White, R.P. (1998). Four essential ways that coaching can help executives. Greensboro: Center for Ccreative Leadership

Wood, R. \& Bandura, A. (1989). Social cognitive theory of organisational management. Academy of Management Review $14(3), 36$. 